DERLEME MAKALE

\title{
Yeni Koronavirüs Hastalığı Pandemisinde Akut İskemik İnmede Hemşirelik Bakımının Yönetimi
}

\author{
Simge KALAV ${ }^{1}$, (iD) Sakine BOYRAZ ${ }^{2}$
}

\begin{abstract}
${ }^{1}$ Araş. Gör. Dr, Aydın Adnan Menderes Üniversitesi, Hemșirelik Fakültesi, İç Hastalıkları Hemșireliği Anabilim Dalı, Aydın, Türkiye.
${ }^{2}$ Prof. Dr., Aydın Adnan Menderes Üniversitesi, Hemşirelik Fakültesi, İç Hastalıkları Hemşireliği Anabilim Dalı, Aydın, Türkiye.
\end{abstract}

\section{Öz}

Pandemi dönemi, akut iskemik inmenin değerlendirilmesinde ve hastaların tedavi ve bakım sürecinde değişiklere neden olmuştur. Bu nedenle yeni koronavirüs hastalığı şüphesi veya varlığı durumunda, akut iskemik inme yönetiminin her aşamasında önemli sorumlulukları bulunan hemşireler tarafından gerçekleştirilen bakımın modifiye edilmesi önem taşımaktadır. Bu derlemede, pandemi döneminde akut iskemik inmenin değerlendirilmesi ve tedaviye özgü bakım yönetimi ele alınmıştır.

Anahtar Sözcükler: COVID-19, Hemşirelik, İskemik İnme, Pandemi, Yeni Koronavirüs Hastalığı.

\section{Management of Nursing Care in Acute Ischemic Stroke in the Novel Coronavirus Disease Pandemic}

Pandemic period has led to changes in the evaluation of acute ischemic stroke and in the treatment and care process of patients. Therefore, it is important to modify the care provided by nurses, who have important responsibilities at all stages of acute ischemic stroke management, in case of suspected or presence of the novel coronavirus disease. In this review, the evaluation of acute ischemic stroke and treatment-specific care management during the pandemic period are discussed.

Key Words: COVID-19, Nursing, Ischemic Stroke, Pandemic, Novel Coronavirus Disease.

Geliş Tarihi / Received: 24.02.2021 Kabul Tarihi / Accepted: 04.08.2021

Correspondence Author: Araş. Gör. Dr, Adnan Menderes Üniversitesi, Hemşirelik Fakültesi, İç Hastalıkları Hemşireliği Anabilim Dalı, Aydın, Türkiye. Telefon: 05392584703 E-posta: skalav@adu.edu.tr

Cite This Article: Kalav S, Boyraz S. Yeni Koronavirüs Hastalığı Pandemisinde Akut İskemik İnmede Hemşirelik Bakımının Yönetimi. Dokuz Eylül Üniversitesi Hemşirelik Fakültesi Elektronik Dergisi. 2021; 14 (4): 453 - 460 
$\mathbf{S}$ iddetli akut solunum sıkıntısı sendromu koronavirüs-2 (SARS-CoV-2) olarak adlandırılan yeni tip koronavirüs, dünya çapında hızla yayılmış ve Dünya Sağlık Örgütü tarafından 11 Mart 2020'de Yeni Koronavirüs Hastalığı (COVID-19) salgını ilan edilmiştir (1-3). COVID-19 yüksek ateş, öksürük, nefes darlığı, baş ağrısı, boğaz ağrısı, burun akıntısı, kas ve eklem ağrısı, halsizlik, koku ve tat alma duyusu kaybı ve ishal gibi belirtilerle kendini göstermektedir. COVID-19 hastalığı pulmoner tutulumun yanı sıra venöz tromboemboli, akut böbrek hasarı, akut karaciğer hasarı, sitokin salınımı, septik şok, yaygın damar içi koagülasyon, gebelik ile ilgili komplikasyonlar ve nörolojik komplikasyonlara neden olabilmektedir (4).

COVID-19'un inme için potansiyel bir risk olduğu, ayrıca inmede morbidite ve mortalitede artışa yol açtı̆g 1 bildirilmektedir (4,5). COVID-19 ve inme ilişkisinin, vasküler risk faktörleri, proinflamatuar ve protrombotik olayları kapsayan çok faktörlü bir etkiden kaynaklandığı belirtilmektedir (6). Qin ve ark., (2020) tarafindan yapılan çalışmada, 1875 COVID-19 hastasının 50'sinde inme öyküsü olduğu bildirilmiştir (7). Aynı çalışmada inme öyküsü olan COVID19 hastalarında, inme öyküsü olmayanlara göre klinik semptomların daha şiddetli ve prognozun daha kötü olduğu rapor edilmiştir. Yaghi ve ark., (2020) tarafindan yapılan çalı̧̧mada, COVID-19 tanısı ile hastanede yatan 3556 hastadan 32 'sinde (\%0.9), manyetik rezonans/bilgisayarlı tomografi (MR/BT) yöntemiyle iskemik inme saptandığı ve bunun pıhtılaşma ile ilişkili olduğu ve mortaliteyi arttırdığı bildirilmiştir (8). Bekelis ve ark., (2020) yaptığı çalışmada, COVID19 ile enfekte olan inme hastalarında mortalitenin, enfekte olmayan inme hastalarına göre daha yüksek olduğu bildirilmiştir (9). Dhamoon ve ark.,'nın (2021) çalışmasında, inme geçiren COVID-19 hastalarında beyin loblarını tutan serebrovasküler olay riskinin COVID-19 ile enfekte olmayan inme hastalarına göre daha yüksek olduğu ve prognozun kötü olduğu bildirilmiştir (10).

COVID-19 pandemisinin inmeye bağlı komplikasyonlar ve mortalite üzerine olumsuz etkileri olduğu görülmektedir. Pandemide hem hastaların hem de sağlık profesyonellerinin güvenliğinin sağlanmasının önem taşıdığı, inme geçiren hastaların sağlı kurumlarına başvuruda gecikmeler yaşandığı ve COVID-19 enfeksiyonlu inmeli hastaların inmeyi daha şiddetli geçirdiği görülmektedir (11).

Bir yandan sağlık profesyonellerinin SARS-CoV-2'ye maruz kalma riskini azaltmaya yönelik kişisel koruyucu ekipmanın sağlanmasının yanı sıra, akut inme hastalarının hızlı ve kapsamlı değerlendirme gereksinimi devam etmektedir (11). COVID-19 pandemisinde akut inme bakımının ve hastanede inme yönetiminin gözden geçirilmesi ve ilave tedbirlerin alınması oldukça önemlidir (12).

Pandemi dönemi göstermiştir ki spesifik tedavisi olmayan hastalıklarda hemşirelik bakımı, yaşamın sürdürülmesi için vazgeçilmezdir (13). COVID-19 ile mücadelenin ön saflarında yer alan hemşireler, kaynak sınırlılıklarına (kişisel koruyucu ekipman gibi) ve yoğun çalışma şartlarına rağmen bakım, eğitim ve danışmanlık rollerini başarılla sürdürmektedir. Özellikle COVID-19'dan ileri derecede etkilenen hastalara yönelik tedavi stratejilerinin önemli bir parçasını, hemşirelik uygulamaları oluşturmuştur (14).

Beyin damar hastalığı olarak da tanımlanan inme, hemorajik ve iskemik olarak iki farklı şekilde gelişmektedir. İnmenin (iskemik ve hemorajik) ayırııı tanısı, tedavi stratejileri açısından hayati önem arz etmektedir. İskemik inmede kullanılan zamana spesifik tedavi yöntemleri açısından erken tanı ve tedavi müdahalesi çok kritiktir. Özellikle COVID19 pandemi sürecinde hasta kabul ve triyaj aşamasında yaşanabilecek gecikmelerin azaltılması çok önemlidir (15). Bu derlemede COVID-19 pandemisinde akut iskemik inmenin değerlendirilmesi (tanı ve tedavi) ve hemşirelik bakım yönetimi tartı̧̧lacaktır.

\section{COVID-19 Pandemi Sürecinde Akut İskemik İnmenin Değerlendirilmesi}

İnme, COVID-19 pandemi sürecinde de acil değerlendirme (tanı ve kritik tedavi kararı) gerektiren bir sağlık sorunu olmaya devam etmektedir. Pandemi sürecinde, şüpheli inme semptomları olan hastaların evlerinde beklemeden acil servise başvurmaları önerilmektedir (16).

İnme şüphesi ile acil servise getirilen hastaların, Sağllk Bakanllğı COVID-19 Erişkin Hasta Tedavisi Rehberi'ne göre triyajının yapılması gerekmektedir. Akut inme hastalarında, acil kapısındaki triyaj sırasında COVID19 varlı̆̆ının saptanmasına yönelik sorulara yanıt alınması zor olabilmektedir $(2,17)$. Çünkü inmeli hastada öykü almayı engelleyebilecek semptomların (afazi, dizartri ve konfüzyon gibi) varlığı, COVID-19 enfeksiyonunu tanımlamadaki zorluklar arasında görülmektedir $(18,19)$. Bu nedenle akut inme semptomları ile acile başvuran hastaların SARS-CoV2 ile enfekte olarak kabul edilmesi önerilmektedir $(2,19,20)$. Acile başvuran hastalarla fiziksel temas halinde olan tüm sağlık personelinin, COVID-19 enfeksiyonu dışlanana kadar "tam kişisel koruyu ekipman (uzun kollu ameliyathane önlügü, cerrahi maske, geniş gözlük, bone, siperlik ve eldiven giyilmesi)" giymesi gerektiği vurgulanmaktadır $(2,16,19)$.

Pandemi döneminde kişisel koruyucu önlemlerle ilgili temel şartların sağlanamadığı durumlarda, tele inme değerlendirmesi yapılabileceği belirtilmekte ve inme bakım sisteminin ayrılmaz bir parçası olarak tanımlanmaktadır. Tele inme değerlendirmesinin, akut inme değerlendirmesinin tüm aşamalarını gerçekleştirmeye olanak sağladığı düşünülmektedir $(2,16,18,19,21,22)$. Tele inme değerlendirmesi, National Institutes of Health Stroke Scale (NIHSS) kullanılarak anında değerlendirme yapılmasına ve trombolitik tedavi ya da trombektomi uygunluğunun belirlenmesine olanak tanıdığı için "yatak başı değerlendirmeye" eşdeğer gösterilmektedir (18). Düşük maliyetli akıllı telefon uygulaması da akut inmenin hızlı değerlendirilmesinde diğer bir seçenek olarak görülmektedir $(18,23)$.

Pandemi sürecinde acil serviste akut inmenin değerlendirilmesine yönelik öneriler aşağıda belirtilmektedir (2,6,16-19,23-25). Bunlar;

- İnme şüphesi ile gelen tüm hastaların COVID-19 açısından taranması (Polimeraz Zincir Reaksiyonu $=$ PCR testlerinde kullanılmak üzere hastalardan orofaringeal-nazofaringeal sürüntü örneği alınmasi)

- Hastada; 
- COVID-19 semptomlarının (özellikle ateş, öksürük, göğüs ağrısı, nefes darlığı, anozmi (koku duyusunda kayıp), baş ağrısı, miyalji, kusma ve diyare gibi) olması,

- COVID-19 tanısı olan kişilerle temas öyküsü olması,

- Hastanın veya hastayla temas öyküsü olan bireylerin seyahat öyküsünün pozitif olması,

- Pandemi kurallarına yetersiz uyum şüphesinin olması,

- Son 14 gün içinde herhangi bir pandemi hastanesine herhangi bir nedenle gidilmiş olmasi,

- Hastadan/yakınından yeterli ya da güvenilir öykü alınamaması,

- İletişimi bozan durumların olması (afazi veya bilincin kapanması gibi) halinde Korumalı İnme Protokolü’nün uygulanması (Tablo 1),

- Hastanelerde COVID-19'a yönelik ayrı bir tarama alanı olması, acil görüntüleme işlemlerinde ayrı bir yolun oluşturulması, tüm görüntüleme alanlarının acil durumlarla ilgili görüntüleme alanlarından ayrılması (örneğin; acil servisten ayrı konsültasyon odaları/BT odaları olması gibi),

- SARS-CoV-2 bulaş riskini azaltmak için, hastayı değerlendiren inme ekibi üyelerinin minimum sayıda tutulmas1,

- SARS-CoV-2 bulaş riski yüksek olan sağlık personellerinin mümkün olduğunca değerlendirme aşamasına dahil edilmemesi ve bahsedilen tüm işlemler sırasında sağlık personeli ve hasta arasında uygun mesafenin korunması önerilmektedir.

\section{Tablo 1. Korumalı İnme Protokolü}

- Aerolizasyon riski yoksa tam kişisel koruyucu ekipmanın uygun şekilde giyilmesi

- Aerolizasyon riski varsa, aerolizasyona yol açabilecek işlemlerden (orofaringeal/nazal aspirasyon, nebülizasyon, nazo/oro-enterik tüp/beslenme tüpü takılması, non-invaziv mekanik ventilasyon, kardiyo-pulmoner resusitasyon, kusma, öksürme, aksırma gibi hasta sekresyonuna maruz bırakabilecek durumlar) sadece mutlak gerekli olanların yapılması, kişisel koruyucu ekipmanlara N95 maske ve uzun eldivenin eklenmesi ve N95 maske üzerine cerrahi maske takılması

- El hijyeni protokolüne eksiksiz uyum sağlanması

- Entübe olmayan hastalara cerrahi maske takılması ve bu maskelerin tetkikler/transferler sırasında çıarılmaması

- Hastanın bilinç durumu kötüleşiyorsa/nörolojik endikasyon varsa, işlemler esnasında yüksek oksijen gereksinimi olasılığı varsa erken entübasyon gerçekleştirilmesi

Tablo içindeki bilgiler Topçuoğlu ve ark. (2) kaynağından uyarlanmıştır.

Pandemi döneminin, akut inme yönetiminin kalitesinde esnekliklere yol açmaması gerektiği vurgulanmakta ve hastaların bu dönemde de mevcut kılavuzlara uygun şekilde değerlendirilmesi önerilmektedir (2). İnmeli hastaların acil ünitelerinde ayırıcı tanı ve tedavisi Akut İskemik Inme Tanı ve Tedavi Rehberi (2020)'nde (24), Akut İskemik Inmede İntravenöz Doku Plazminojen Aktivatörü (tPA) Kullanım Cep Kitabl)'nda (25) ve Akut İnmeli Hastalara Verilecek Sağllk Hizmetleri Hakkinda Yönerge'de (26) yer alan bilgiler doğrultusunda yapılmalıdır. İnme değerlendirme klavuzlarına göre;

- Hastanın hava yolu açıklığının, solunum ve dolaşım fonksiyonlarının sürdürülmesi (nazal kanül ile oksijen desteğinin satürasyon seviyesi $\leq \% 94$ ise kullanılması, hipoksik olmayan hastalarda kullanılmaması; vital bulguların ölçümü, trombolitik tedavi adayı olan akut iskemik inme hastalarının sistolik basıncı $185 \mathrm{mmHg}$ ve diastolik basıncı $110 \mathrm{mmHg}$ üzerinde değilse kan basıncına (KB) müdahale edilmemesi),

- Genel sağlık durumunda bozulmaya neden olabilecek sorunların düzetilmesi (diyabetik inmeli hastalarda kan glikoz düzeyinin 140-180mg/dL aralığında tutulması, $60 \mathrm{mg} / \mathrm{dl}$ seviyesi altındaki hipogliseminin düzeltilmesi; koagülopatinin düzeltilmesi),

- Trombolitik tedavi uygunluğunun hızlıca değerlendirilmesi,

- Semptomların patofizyolojik temelinin anlaşılmasına yönelik tetkiklerin yapılması; nörolojik muayene yapılması, elektrokardiyogram/EKG çekilmesi, kan örneklerinin gönderilmesi, inmenin ayırıcı tanısında BT/MR ile değerlendirilme yapılması ve parenkimal görüntülemenin başvuru sonrası 20-25 dakika içerisinde tamamlanması gerekmektedir.

Görüntüleme yöntemleri ile inme tanılaması (hemorajik ya da iskemik) yapıldıktan sonra uygun tedavi protokolü uygulanmalıdır (27). Akut iskemik inmenin hiperakut dönemde (semptomların başlamasından sonraki ilk altı saat) hızlıca tanılanması ve hastanın zamana spesifik tedaviye (trombolitik ve/veya nöroendovasküler girişim) uygunluğunun değerlendirilmesi kritik önem arz etmektedir (24).

\section{COVID-19 Pandemi Sürecinde Akut İskemik İnme Tedavisi ve Hemşirelik Bakımı}

Akut iskemik inme tedavisinde onay almış tedaviler "intravenöz trombolitik tedavi (İ.V. rekombinant insan doku tipi plazminojen aktivatörü=rt-PA)" ve "nöroendovasküler tedavi"dir. Zaman kavramının oldukça önemli olduğu bu tedavi yöntemlerinde üç temel prensip; rekanalizasyon ve reperfüzyon, kolletarel kan akımının normale dönmesi ve ikincil beyin hasarının önlenmesi olarak belirtilmektedir $(24,27)$. Akut iskemik inme tedavisine yönelik uygulama prensiplerinin, $S A R S-C o V-2$ ile enfekte olan ya da enfeksiyon şüphesi bulunan hastalarda değişiklik göstermediği, hastaların COVID-19 testi sonuçlarının pozitif ya da negatif olması fark etmeksizin İ.V. rt-PA ve nöroendovasküler tedavi yöntemlerinden faydalanabileceği belirtilmektedir (2). Bununla birlikte, pandemi sürecine özgü önlemlerin alınması gerekli görülmektedir $(2,18)$. COVID-19 pandemisinde, belirtilen üç temel prensibin gerçekleştirilmesi 
sırasında, inme ekibi tarafından tam kişisel koruyucu ekipman kullanılması, özel önlemlerin alınması ve kanıta dayalı bakımdan vazgeçilmemesi önerilmektedir $(2,28,29)$.

\section{COVID-19 Pandemi Sürecinde Intravenöz Trombolitik Tedavi ve Hemşirelik Yönetimi}

Akut iskemik inme tedavisinde kullanılan İ.V. rt-PA tedavisi, pıhtı ile tıkanan damar içinde oluşan fibrinin plazmin ile eritilmesi ve böylelikle penumbra dokusunun kurtarılması amacıyla kullanılmaktadır. Sağlıklı bireyde normal olarak damar endotel hücrelerinden salgılanan doku plazminojen aktivatörünün (t-PA) tromboliz ve trombogenez dengesini sağlamada önemli rolü bulunmaktadır. t-PA plazminojenin plazmine dönüşümünü katalize etmekte, plazmin fibrini yıkmakta ve böylece intravasküler fibrinolitik (trombolitik) etki oluşmaktadır (30-32). Dışardan İ.V. olarak verilen rtPA'nın inme semptomlarının ortaya çıktığı veya vakanın son normal görüldüğü andan itibaren ilk 4.5 saat içerisinde uygulanması gerekmektedir. COVID-19 pandemisi döneminde İ.V. rt-PA alan hastaların mevcut inme kılavuzlarına göre izlenmesi, hastanın acil servise girişi ile tedavinin başlaması arasındaki sürenin 60 dakikayı geçmemesi (hastane içi gecikmenin engellenmesi) önerilmektedir (15).

COVID-19 pandemisinde İ.V. rt-PA uygulaması öncesinde yapılması gerekenler aşağıda özetlenmiştir $(2,16,18,24,27)$. Bunlar;

- COVID-19 koruyucu önlemlerin alınması Korumalı İnme Protokolü’nün uygulanması,

- Oksijenasyonun sağlanması,

- Etkili kan basıncı kontrolü,

- Yeterli fizik muayene, nörolojik muayene ve NIHSS inme skoru değerlendirmesi,

- İki farklı damar yolu açılması (\%0.9 NaCl kullanılmalı. \%5 Dekstroz kullanımından kaçınılmalı),

- Temel biyokimya, tam kan sayımı, kan grubu, aPTT (aktive parsiyel tromboplastin zamanı), INR (international normalized ratio/uluslararası normalleştirilmiş oran) ve kan şekerinin değerlendirilmesi,

- Hastane politikaları 1 şı̆̆ında bilgilendirilmiş onamların alınması (rızadan feragat etme veya uzaktan elektronik bilgilendirilmiş onam alınması gibi yöntemler gerekebileceği unutulmamalıdır),

- Hasta için zorunlu ise, invaziv girişimlerin (endotrakeal tüp, nazogastrik tüp gibi) rt-PA uygulamadan önce yapılmas1,

- rt-PA hazırlama aşamalarınının “İnme Hemşireliği Standartlar ve Pratik Uygulamalar Kılavuzuna” göre yapilmasi (26)

- $\quad$ İ.V. rt-PA dışlama kriterlerinin son kontrolünün yapılmasıdır.

İntravenöz trombolitik tedavi uygulaması sırasında ve sonrasında yapılması gerekenler aşağıdaki şekilde özetlenmiştir (2,24,26). Bunlar;

- Takip ve komplikasyonlarda (kanama, anjioödem gibi) gerekecek olan tüm uygulamaların yazılı ve önceden çalışılmış olması,

- Kan basıncının rt-PA uygulama sırasında ve sonrası 2 saat için 15 dakikada bir, takip eden 6 saat 30 dakikada bir ve sonraki 16 saatte 60 dakikada bir takip edilmesi,

- İ.V. rt-PA infüzyonu süresince hastanın 15 dakikada bir bilinç (NIHSS kullanılarak), motor defisit, majör ve minör kanama, orolingual ödem ve kafa içi basınç artışı sendromu (KİBAS) belirtileri yönünden izlenmesi,

- $\quad$ I.V. rt-PA infüzyonu bittikten sonraki 6 saat 30 dakikada bir ve kalan 16 saat boyunca 60 dakikada bir hastanın nörolojik değişiklikleri (bilinç, pupilla 1şık reaksiyonu ve motor defisit), major ve minör kanama belirtileri, KİBAS belirtileri, aşırı duyarlılık ve anjioödem belirtileri yönünden izlenmeye devam edilmesi, 24. saatte NIHSS değerlendirmesinin tekrarlanması,

- İ.V. rt-PA tedavisine bağlı gelişebilecek komplikasyonlara yönelik izlemlerin yanı sıra yaşam bulguları, kan glikozu ve sıvı desteğine yönelik izlemlerin ve girişimlerin başlatılması;

- Kan basıncinın 180/105 mmHg altında tutulmasi,

- Diyabetik inmeli hastalarda ilk 24 saat kan glikozu değerinin 140-180 mg/dL arasında tutulmasının hedeflenmesi, hipogliseminin $(<60 \mathrm{mg} / \mathrm{dl})$ tedavi edilmesi,

- Hipertermi $\left(>38^{\circ} \mathrm{C}\right)$ varsa soğuk uygulamaya başlanması, enfeksiyon kaynaklarının tespit ve tedavi edilmesi,

- Hava yolu açıklığının sürdürülmesi,

- Hastanın sırtüstü pozisyonda yatırılması, hastanın başının vücudu ile nötral pozisyonda olacak şekilde (başın etkilenen tarafa yığılması engellenmeli) olması ve duruma göre yatak başucunun $15-30^{\circ}$ kaldırılması,

- Kardiyak ritim takibi için monitörize edilmesi,

- Destek tedavi olarak gerektiğinde sıv1 replasman tedavisinin (2ml/saat/24 saat) yapılması,

- Uygulama sırasında yeni bir nörolojik bozukluk veya kötüleşme gelişmesi durumunda tedavinin durdurulması, durumun doktora bildirilmesi ve hastanın acilen BT'ye gönderilmesi,

- İ.V. rt-PA tedavisi sonrası en az 24 saat kesinlikle aspirin, klopidogrel, İ.V. heparin, düşük molekül ağırlıklı heparin verilmemesi,

- Antikoagülan veya antiplatelet ajanlara başlanmadan önce standart olarak 24. saatin bitiminde kontrol BT’si (veya MRG) istemi için hekimle işbirliği yapılması,

- Korumalı İnme Protokolü doğrultusunda İ.V. rt-PA uygulanan hastaların PCR test sonucu negatif gelince inme ünitesinde takip edilmesi, 
- Korumalı İnme Protokolü doğrultusunda İ.V. rt-PA uygulanan hastalardan nöroloji yoğun bakımı gereksinimi olanların PCR test sonuçları negatif gelince nöroloji yoğun bakımda takip edilmesi,

- İnme ünitesinde ve nöroloji yoğun bakımda aerolizasyon koruması olmadığı durumlarda, hastaların ancak COVID-19 varlığı dışlanınca bu ünitelerde takip edilmesi,

- Birinci hafta NIHSS ve modifiye Rankin Skoru'nun (mRS) değerlendirilmesi ve taburcu olurken bu değerlendirmelerin tekrarlanmasıdır.

COVID-19 Pandemi Sürecinde İskemik İnme Tedavisinde Nöroendovasküler Girişim ve Hemşirelik Yönetimi

Nöroendovasküler girişim diğer bir deyişle mekanik trombektomi, kan akışının geri kazanılması ve kalıcı doku hasarının en aza indirilmesi için mekanik olarak pıhtının dışarı çıkartılmasını hedefleyen bir tedavi yöntemidir. Şüpheli/doğrulanmış COVID-19 enfeksiyonu olan iskemik inmeli hastalarda invaziv prosedürlerin gerçekleştirilmesiyle ilişkili karmaşıklıklar göz önüne alındığında, mekanik trombektomiye uygun hastaların seçimi konusunda sıkı bir politika uygulanması gerekli görülmektedir. Prosedürün gerçekleştirilmesi için vaka bazında karar verilmesi gerektiği vurgulanmaktadır. Semptomları başladıktan sonrası ilk altı saat içinde başvuran akut iskemik inme hastalarında endovasküler tedavi kararı vermek için kontrastsız serebral BT ve BT anjiyografi tetkiki yapmanın yeterli olduğu belirtilmektedir. Mekanik trombektomi işlemindeki gecikmeleri önlemek için hastanın COVID-19 ile enfekte olduğu varsayılarak, uygun önlemlerle işleme başlanması önerilmektedir $(17,18,24,27)$. SARS-CoV-2 virüsü kontamine çevresel yüzeylerden ve ekipmanlardan sağlık profesyonellerine ve diğer hastalara bulaşabileceği için, anjiyografi alanında hijyene yönelik protokollerin uygulanması önemli görülmektedir (34). SARS-CoV-2'ye karş1 etkisi kanıtlanmış hastane dezenfektanlarıyla çalışma yüzeylerinin ve ekipmanların dezenfekte edilmesi, hastanın kanı veya sekresyonuyla temas edebilecek salin veya kontrastın kapalı sistemler kullanılarak atılması önerilmektedir. Bulaş riskini azaltmaya yönelik hijyen protokollerinin yönetici hemşireler tarafından ele alınması önemlidir (18).

SARS-CoV-2 enfeksiyonunun ortaya çıkmasından önceki standart önlemler; kateterlerin yerleştirilmesinde veya kılavuz tel değişiminde görev alan tüm sağlık profesyonellerinin başlık, standart cerrahi/tıbbi maske, göz koruması, steril (gözeneksiz) önlük ve steril eldivenlerden oluşan kişisel koruyucu ekipmanlar kullanması olarak belirtilmektedir. Ancak COVID-19 pandemi sürecinde tüm kateterizasyon laboratuvarı personelinin koruyucu inme protokolüne uygun şekilde kişisel koruyucu ekipmanlar giymesi, partikül filtreli yüz maskesi (N95 ya da FFP2 veya FFP3 standardında ya da eşdeğer) ve göz koruyucu kullanması gerektiği vurgulanmaktadır (18,33). SARS-CoV-2 enfeksiyonu olan hastalarda hipoksik solunum yetmezliği gelişebilmekte, bu nedenle mekanik trombektomi sırasında acil entübasyon, sakşın ve kardiyopulmoner resüsitasyon gibi aeroliasyona neden olabilecek işlemlere gereksinim duyulabilmektedir. Planlanmamış entübasyonlardan kaçınmak için mekanik ventilasyon ve genel anestezi uygulama eşiğinin düşük olması önerilmektedir $(18,33)$.

Mekanik trombektomi girişiminde hemşirenin sorumluluklarının ve işlem öncesi/sırası/sonrasında gelişebilecek komplikasyonların yönetiminin, pandemi sürecinde de mevcut kılavuzlarda belirtilen şekilde ele alınması önerilmektedir $(17,27)$. Nörogirișimsel işlem süresince bakım yönetimi; hava yolu açıklığının sürdürülmesi, kan basıncı takibi ve müdahalesi, İ.V. rt-PA'ya bağlı anjioödemin takibi ve müdahalesinin sağlanması, kontrast madde alerjisine müdahale edilmesi, İ.V. rt-PA sonrası erken intraserebral kanama takibi, bilinç değişikliği, anormal pupilla reaksiyonu, motor defisitte kötüleşme gibi belirtilerin takip edilmesi, başın stabilizasyonun sağlanması/sürdürülmesi olarak belirtilmiştir (27).

Nörogirişimsel işlem sonrası takipte temel ilkeler ve yaklaşımlar ise; bilinç ve nörolojik status takibi, devamlı kardiyak monitorizasyon uygulaması ve ponksiyon bölgesinin takibi (alt ekstremitede nabız kontrolü, kanama takibi, renk, hareket, duyu takibi, 4-6 saat yatak istirahatinin sağlanması) şeklindedir (27). Nörogirişimsel tedavi döneminde hemşirenin genel sorumlulukları; pulse oksimetre ile oksijen satürasyonu takibi (>\%95 üzerinde tutulmaya çalışılması), vücut 1 sısı ve kan şekeri takibi $(<180 \mathrm{mg} / \mathrm{dl}$ düzeyinde tutulmaya çalışılması), derin ven trombozu profilaksisi, hasta tolere edebiliyorsa 24 saat içinde erken mobilizasyon denemesi, tüm invazif prosedürlerin dikkatlice düşünülmesi (gerekliyse rt-PA infüzyonundan en az bir saat sonra uygulanması), düşme riski değerlendirmesi yapılması/önlemlerin alınması, IV rt-PA uygulanmışsa aspirin, clopidogrel, dipridamole veya antikoagulan ilaçların takip eden 24 saat boyunca verilmemesi, yutma değerlendirmesi yapılana kadar oral alımın durdurulması olarak belirtilmektedir (27).

\section{COVID-19 Pandemi Sürecinde Akut İskemik İnmenin Yoğun Bakım Sürecindeki Yönetimi}

COVID-19 pandemisinde, yoğun bakım ünitesi (YBÜ) yataklarına olan taleplerde artış olduğu bilinmektedir. Bu nedenle hastaların YBÜ'ye kabul şartlarından biri olarak inmeye bağl tahmini mortalite kriterinin düşünülmesi önerilmektedir (19). Amerikan Kalp Derneği Birliği/Amerikan İnme Derneği (American Heart Association/American Stroke Association) tarafindan hazırlanan COVID-19 geçici acil rehberinde, IV trombolitik/nöroendovasküler girişim sonrasında durumu stabil olan hastaların yoğun bakım dışındaki ünitelerde takip edilebileceği belirtilmektedir (20). COVID-19 pandemi sürecinde dispne ve solunum yetmezliği olan inme hastalarının ise yoğun bakımda takip edilmesi önerilmektedir $(35,36)$. Sağlık Bakanlığı tarafından 2019 yılında yayınlanan Akut Inmeli Hastalara Verilecek Sağllk Hizmetleri Hakkında Yönerge'de 24-72 saatlik süreçte nöroloji yoğun bakım ünitesinde yapılacak işlemler; risk faktörlerinin taranması, 24. saat kontrol görüntülemesi, 24. saat NIHSS skorunun kaydedilmesi, eksik parenkim görüntülemesinin tamamlanması, eksik vasküler görüntülemenin tamamlanması, kardiyak monitorizasyon, disfaji taraması, antitrombotik tedavi, derin ven trombozu profilaksisi ve mobilizasyon olarak belirtilmektedir (26).

COVID-19 inme hastalarının yoğun bakımdaki tedavileri sırasında hemşireler tarafından ele alınması gereken konular; enfeksiyon kontrolü, solunum desteği yaklaşımları, beslenme, koagulopati, septik şok yönetimi ve sıvı resüsitasyonu, böbrek yetersizliği ve kardiyopulmoner resüsitasyon olarak belirtilmektedir (36-40).

Yoğun bakımda hasta ile uzun süre boyunca yakın temas halinde çalışan yoğun bakım hemşirelerinin enfeksiyon kontrolüne yönelik tam kişisel koruyucu ekipmanlar kullanması önerilmektedir (36,37). Aerosol ve damlacık 
maruziyetini en aza indirmek için bakımın ideal olarak negatif basınçlı odalarda gerçekleştirilmesi gerektiğine dikkat çekilmektedir $(18,36)$. Hava yoluyla bulaş riskini en aza indirebilmek için oda içerisinde saatte 12 kez hava değişimi sağlanması, negatif basınçlı odalar mevcut olmadığında ise oda kapılarının kapalı tutulması ve oda sayısının arttırılması önerilmektedir (36-38). Uygun oda şartları sağlanamadığı durumlarda hastaların en az 1-1.5 metre mesafe ile ayrılmış alanlarda bakılması gerektiği vurgulanmaktadır (36).

Dispnesi olan hastalarda sıklıkla invaziv olmayan solunum destek sistemlerinin kullanılması, solunum fonksiyonlarının sık aralıklarla takip edilmesi, aerosol oluşumu ile sağlık çalışanlarının bulaş riskini artırabilecek işlemlerde uygun koruyucu önlemlerin alınması önerilmektedir $(28,36)$. Akciğer tutulumu olan entübe edilmemiş COVID-19 hastalarında pron pozisyonu uygulamasının hipoksemi üzerine olumlu etkileri olduğu, oksijenasyonu arttırarak entübasyonu önlediği belirtilmektedir $(28,36,41)$. Entübe akut respiratuvar distres sendromu hastalarında, optimal mekanik ventilatör ayarlarına rağmen hipokseminin düzelmemesi durumunda, 12-16 saat pron pozisyon uygulanabileceği, bununla birlikte ortaya çıkabilecek riskler (basınç yarası, kateter veya endotrakeal tüpün çıması, hemodinamik instabilite ve brakial pleksus yaralanması gibi) açısından hastanın yakından takip edilmesi ve risk değerlendirmesi yapılması önerilmektedir $(36,42)$.

COVID-19 hastalı̆̆ına septik şok tablosunun eşlik etmesi durumunda hipervolemiden kaçınılması mekanik ventilasyon süresini ve yoğun bakım ünitesinde kalıs süresi azaltabilmektedir. Ayrıca akut respiratuvar distres sendromu hastalarında dengeli solüsyonlar tercih edilerek sıvı tedavisinin dikkatli yürütülmesi önerilmektedir $(36,39)$. Bununla birlikte noninvaziv veya invaziv arter basıncı, oksijen satürasyonu, EKG, vücut sıcaklığı ve idrar çıkışı takibinin önemi vurgulanmaktadır. Standart monitörizasyon tekniklerine ek olarak ciddi solunum yetmezliği olan mekanik ventilatördeki hastalarda end-tidal $\mathrm{CO}_{2}$ ölçümü ve sürekli vücut sıcaklığı takibi; ciddi pnömoni, sepsis, septik şok ya da kardiyak yetmezlik gelişen hastalarda ise santral venöz kateterizasyon takibi önerilmektedir (42). Kapiller geri dolum, sıvı infüzyonuna yanıtı ve perfüzyonunu değerlendirmesi de önemli görülmektedir. Yoğun bakım ünitesindeki hastalara yönelik beslenme yaklaşımlarının COVID-19 pandemi sürecinde de geçerli olduğu vurgulanmaktadır (36).

Yoğun bakımda yatan COVID-19 hastalarında, tromboembolinin önlenmesi için heparin profilaksisi uygulanması, uygulanacak olan düşük molekül ağırlıklı heparin dozunun hastanın D-dimer düzeyine göre belirlenmesi gerektiği belirtilmiştir $(36,43)$. Hastaların ayrıca hematüri, proteinüri, ödem, hipertansiyon, oligüri varlı̆̆ açısından takip edilmesi önerilmektedir (36,44). Kardiyopulmoner resüsitasyonun Erişkin İleri Yaşam Desteği Algoritması'na, göre gerçekleştirilmesi gerektiği vurgulanmaktadır $(28,36,40)$.

\section{Sonuç}

COVID-19 pandemisinde akut iskemik inme yönetiminde hemşireler önemli bir rol üstlenmektedir. Sağllk profesyonelleri olarak hemşirelerin, doğrulanmış ya da şüpheli COVID-19 hastalığının eşlik ettiği akut iskemik inmede hastalı̆̆ın değerlendirilmesi, akut iskemik inme tedavisi ve inmenin yoğun bakım sürecindeki yönetimi konusundaki sorumluluklarını, sürekli yenilenen rehberleri takip ederek yerine getirmeleri önerilir. Bu süreçte akut iskemik inme tedavisi ve bakımına yönelik uygulama prensiplerinin pandemi sürecine özgü önlemler alınarak ve kanıta dayalı bakım ilkeleri doğrultusunda sürdürülmesi önem taşımaktadır.

\section{Bilgilendirme}

Yazarların katkı oranı eşittir. Yazarlar arasında çıkar çatışması bulunmamaktadır. Makalede araştırma ve yayın etiğine uyulmuştur. 


\section{Kaynaklar}

1. World Health Organization. Naming the coronavirus disease (COVID-19) and the virus that causes it.URL:https://www.who.int/emergencies/diseases/novel-coronavirus-2019/technical guidance/naming-thecoronavirus-disease-(covid-2019)-and-the-virus-that-causes-it. 22 Şubat 2021

2. Topçuoğlu MA, Arsava EM, Özdemir AÖ. COVID-19 pandemisinde akut iskemik inme tedavisi: uzman görüşü. Türk Beyin Damar Hast Derg 2020;26(1):1-4.

3. World Health Organization. WHO Director-General's opening remarks at the media briefing on COVID-19 - 11 March 2020. URL:https://www.who.int/director-general/speeches/detail/who-director-general-s-openingremarks-at-the-media-briefing-on-covid-19-11-march-2020. 22 Şubat 2021

4. Özen Barut B, Güçlü Altun İ. Neurological complications related with COVID-19. URL: https://jag.journalagent.com/scie/pdfs/SCIE-78557-REVIEW-BARUT.pdf. 28 Haziran 2021

5. Mathew T, John SK, Sarma G, Nadig R, Kumar RS, Murgod U, et al. COVID-19-related strokes are associated with increased mortality and morbidity: A multicenter comparative study from Bengaluru, South India. URL: https://www.ncbi.nlm.nih.gov/pmc/articles/PMC7723737/. 28 Haziran 2021

6. Bhatia R, Sylaja PN, Srivastava MVP, Khurana D, Pandian JD, Suri V, et al. Consensus statement - suggested recommendations for acute stroke management during the COVID-19 pandemic: expert Group on Behalf of the Indian Stroke Association. Ann Indian Acad Neurol. 2020;23(Suppl 1):15-23.

7. Qin C, Zhou L, Hu Z, Yang S, Zhang S, Chen M, et al. Clinical characteristics and outcomes of covid-19 patients with a history of stroke in Wuhan, China. Stroke 2020;51(7):2219-2223.

8. Yaghi S, Ishida K, Torres J, Mac Grory B, Raz E, Humbert K, et al. SARS-CoV-2 and stroke in a New York healthcare system. Stroke 2020;51(7):2002-2011.

9. Bekelis K, Missios S, Ahmad J, Labropoulos N, Schirmer CM, Calnan DR, et al. Skinner J, MacKenzie TA. Ischemic stroke occurs less frequently in patients with COVID-19: a multicenter cross-sectional study. Stroke 2020;51(12):3570-3576.

10. Dhamoon MS, Thaler A, Gururangan K, Kohli A, Sisniega D, Wheelwright D, et al. Acute Cerebrovascular Events With COVID-19 Infection. Stroke 2021;52(1):48-56.

11. Markus HS, Brainin M. COVID-19 and stroke-a global World Stroke Organization perspective. Int J Stroke 2020;15(4):361-364.

12. Meyer D, Meyer BC, Rapp KS, Modir R, Agrawal K, Hailey L, et al. A Stroke Care Model at an Academic, Comprehensive Stroke Center During the 2020 COVID-19 Pandemic. J Stroke Cerebrovasc Dis 2020;29(8):104927.

13. Oliveira KKD, Freitas RJM, Araújo JL, Gomes JGN. Nursing Now and the role of nursing in the context of pandemic and current work. Rev Gaucha Enferm 2020;42(spe):20200120.

14. Catton H. Nursing in the COVID-19 pandemic and beyond: protecting, saving, supporting and honouring nurses. International Nursing Review 2020;67(2):157-159.

15. Powers WJ, Rabinstein AA, Ackerson T, Adeoye OM, Bambakidis NC, Becker K, et al. Guidelines for the early management of patients with acute ischemic stroke: 2019 update to the 2018 guidelines for the early management of acute ischemic stroke: a guideline for healthcare professionals from the american heart association/american stroke association. Stroke 2019;50:344-418.

16. Dafer RM, Osteraas ND, Biller J. Acute Stroke Care in the Coronavirus Disease 2019 Pandemic. J Stroke Cerebrovasc Dis 2020;29(7):104881.

17. T.C. Sağlı Bakanlığı. COVID-19 (SARS-CoV-2 Enfeksiyonu) erişkin hasta tedavisi. URL: https://covid19.saglik.gov.tr/Eklenti/39061/0/covid-19rehberieriskinhastatedavisipdf.pdf. 22 Subat 2021

18. Qureshi AI, Abd-Allah F, Al-Senani F, Aytac E, Borhani-Haghighi A, Ciccone A, et al. Management of acute ischemic stroke in patients with COVID-19 infection: Report of an international panel. Int J Stroke 2020;15(5):540554.

19. Smith EE, Mountain A, Hill MD, Wein TH, Blacquiere D, Casaubon LK, et al. Canadian stroke best practice guidance during the COVID-19 pandemic. Can J Neurol Sci 2020;47(4):474-478.

20. AHA/ASA Stroke Council Leadership. Temporary emergency guidance to us stroke centers during the coronavirus disease 2019 (COVID-19) pandemic: On behalf of the American Heart Association/American Stroke Association Stroke Council Leadership. Stroke 2020;51(6):1910-1912.

21. Silva GS, Schwamm LH. Use of telemedicine and other strategies to increase the number of patients that may be treated with intravenous thrombolysis. Curr Neurol Neurosci Rep 2012;12:10-16.

22. Agarwal S, Day DJ, Sibson L, Barry PJ, Collas D, Metcalf K, et al. Thrombolysis delivery by a regional telestroke network--experience from the U.K. National Health Service. J Am Heart Assoc 2014;3(1):000408.

23. Rodríguez-Pardo J, Fuentes B, Alonso de Leciñana M, Campollo J, Calleja Castaño P, Carneado Ruiz J, et al. Acute stroke care during the COVID-19 pandemic. Ictus Madrid Program recommendations. Neurologia 2020;35(4):258-263.

24. T.C. Sağlık Bakanlığı. Akut iskemik inme tanı ve tedavi rehberi 2020. URL:https://bdhd.org.tr/akut-iskemik-inmetani-ve-tedavi-rehberi-2020/. 23 Şubat 2021

25. Türk Nöroloji Derneği Beyin Damar Hastalıkları Bilimsel Çalışma Grubu. Akut iskemik inmede intravenöz doku plazminojen aktivatörü (tPA) kullanım cep kitabı. URL: https://www.noroloji.org.tr/haber/604/akut-iskemikinmede-intravenoz-doku-plazminojen-aktivatoru-tpa-kullanim-cep-ki. 23 Șubat 2021 
26. T.C. Sağlık Bakanlı̆̆ı. Akut inmeli hastalara verilecek sağlık hizmetleri hakkında yönerge https://shgm.saglik.gov.tr/Eklenti/31489/0/akut-inmeli-hastalara-verilecek-saglik-hizmetleri-hakkindayonergepdf.pdf. 22 Şubat 2021

27. Topcuoğlu MA, Tülek Z, Boyraz S, Özdemir AÖ, Özakgül A, Güler A, et al. İnme hemşireliğii: standartlar ve pratik uygulamalar kılavuzu. Türk Beyin Damar Hastaliklari Derneği ve Nöroloji Hemşireliği Derneği ortak strateji projesi. Türk Beyin Damar Hast Derg 2020;26(1):1-90.

28. Khosravani H, Rajendram P, Notario L, Chapman MG, Menon BK. Protected code stroke: hyperacute stroke management during the coronavirus disease 2019 (COVID-19) Pandemic. Stroke 2020;51(6):1891-1895.

29. Baracchini C, Pieroni A, Viaro F, Cianci V, Cattelan AM, Tiberio I, et al. Acute stroke management pathway during Coronavirus-19 pandemic. Neurol Sci 2020;41(5):1003-1005.

30. Ouriel K. A history of thrombolytic therapy. J Endovasc Ther 2004;11(Suppl 2):128-133.

31. Hasanoğlu HC. Trombolitik tedavi: kime, ne zaman, nası1? Güncel Göğüs Hastalıkları Serisi 2015; 3(1):34-44.

32. Topcuoğlu MA, Arsava EM, Özdemir AÖ, Gürkaş E, Necioğlu Örken D, Öztürk Ş. Akut inme tedavisinde intravenöz trombolitik tedavi: Sorunlar ve çözümler. Turk J Neurol 2017;23:162-175.

33. Welt FGP, Shah PB, Aronow HD, Bortnick AE, Henry TD, Sherwood MW, et al. Catheterization laboratory considerations during the coronavirus (COVID-19) pandemic: from the ACC's Interventional Council and SCAI. J Am Coll Cardiol 2020;75(18):2372-2375.

34. van Doremalen N, Bushmaker T, Morris DH, Holbrook MG, Gamble A, Williamson BN, et al. Aerosol and surface stability of SARS-CoV-2 as compared with SARS-CoV-1. N Engl J Med 2020;382(16):1564-1567.

35. T.C. Sağlık Bakanlı̆̆ Halk Sağlığı Genel Müdürlüğü. COVID-19 (SARS-CoV-2 enfeksiyonu) rehberi (14 Nisan 2020). URL:https://covid19bilgi.saglik.gov.tr/depo/rehberler/COVID-19_Rehberi.pdf. 22 Şubat 2021

36. Kebapcı A. COVID-19 hastaların yoğun bakım ünitelerinde tedavi ve bakım girişimlerine ilişkin güncel yaklaşımlar. Yoğun Bakım Hemşireliği Dergisi 2020;24(EK-1):46-56.

37. Brewster DJ, Chrimes N, Do TB, Fraser K, Groombridge CJ, Higgs A, Humar MJ, Leeuwenburg TJ, McGloughlin S, Newman FG, Nickson CP, Rehak A, Vokes D, Gatward JJ. Consensus statement: Safe Airway Society principles of airway management and tracheal intubation specific to the COVID-19 adult patient group. Med J Aust 2020;212(10):472-481.

38. Miller GA, Buck CR, Kang CS, Aviles JM, Younggren BN, Osborn S, et al. COVID- 19 in Seattle-early lessons learned. Journal of the American College of Emergency Physicians Open 2020;1(2):85-91.

39. Türk Yoğun Bakım Derneği (TYBD). COVID-19 ilişkili septik şok tedavisi - TYBD bilimsel görüşü. URL:https://www.yogunbakim.org.tr/haberler/7670/COVID-19-İlişkili-Septik-Şok-Tedavisi---TYBD-BilimselGörüşü. 22 Şubat 2021

40. Resusitasyon Derneği. (2020). COVID-19 Hastaları için erişkin ileri yaşam desteği algoritması. URL:http://resusitasyon.org/tr/etkinlikler-haberler/291-covid-19-hastalari-icin-eriskin-ileri-yasam-destegialgoritmasi.html. 22 Şubat 2021

41. Ding L, Wang L, Ma W, He H. Efficacy and safety of early prone positioning combined with HFNC or NIV in moderate to severe ARDS: a multi-center prospective cohort study. Crit Care 2020;24:28.

42. Rollas K, Şenoğlu N. Covid-19 hastalarının yoğun bakım ünitesinde yönetimi. Tepecik Eğitim ve Araştırma Hastanesi Dergisi 2020;30(Ek say1):142-155.

43. Klok FA, Kruip MJHA, van der Meer NJM, Arbous MS, Gommers DAMPJ, Kant KM, et al. Incidence of thrombotic complications in critically ill ICU patients with COVID-19. Thromb Res 2020;191:145-147.

44. Li Z, Wu M, Yao J, Guo J, Liao X, Song S, et al. Caution on kidney dysfunctions of COVID-19 patients (2020). URL: https://www.medrxiv.org/content/10.1101/2020.02.08.20021212v2. 22 Şubat 2021 